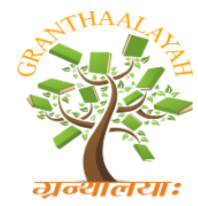

INTERNATIONAL JOURNAL OF RESEARCH GRANTHAALAYAH A knowledge Repository

Management

\title{
GEOGRAPHICAL INDICATIONS IN INDIA \& THE CASE OF FAMOUS INDIAN WEAVE: BANARASI BROCADE
}

\author{
Shruti Gulati ${ }^{* 1}$ \\ ${ }^{* 1}$ Department of Commerce, Delhi University, India
}

DOI: https://doi.org/10.29121/granthaalayah.v4.i12.2016.2402

\begin{abstract}
A milestone was reached when WTO through TRIPS had granted goods to retain its essence of the land by allowing attaching a geographical indication to goods having specialty from the place of origin. Where a product holds characteristics that clearly indicate its reference to a place in terms of quality, essentially attributed things such as reputation, it is said to have a geographical indication. Where most things become synonymous with the land, that they sometimes lose their own identity leading to an interchangeable use of the geographical name with the good like the 'banarasi brocade'or 'phulkari'. The reason for getting it under the Intellectual Property Right radar is that it becomes the selling point as well as that characteristic which solely differentiates the good out of the crowd, sometimes to an extent of premium pricing as well. It's like a safeguard to both the consumers for an assurance of quality and the producers for making it worthy.
\end{abstract}

Keywords: Geographical Indication; Goods; Essence; Registration; Consumer; Producer; Tag; Brocade.

Cite This Article: Shruti Gulati. (2016). "GEOGRAPHICAL INDICATIONS IN INDIA \& THE CASE OF FAMOUS INDIAN WEAVE: BANARASI BROCADE." International Journal of Research - Granthaalayah, 4(12), 137-146. 10.29121/granthaalayah.v4.i12.2016.2402.

\section{Introduction}

According to World Intellectual Property Organisation, Geographical Indications are:

A geographical indication (GI) is a sign used on products that have a specific geographical origin and possess qualities or a reputation that are due to that origin. In order to function as a GI, a sign must identify a product as originating in a given place. In addition, the qualities, characteristics or reputation of the product should be essentially due to the place of origin. Since the qualities depend on the geographical place of production, there is a clear link between the product and its original place of production. 
Even though GI is usually indicative of a geographical area such as a town or a city, it is not necessary that it always has to be linked like that for example, Basmati rice are high quality fragrant rice which see their origin from Pakistan and India.

\section{'Essence of the product is like none other'}

Ranging from international liquor from Champagne, Havana, Tequila, Scotch whisky, Bordeaux, Burgogne to Irish Whisky are all popular examples of finest quality of alcohol arising from geographical indications across the world. This has gained reputation historically from ancient times not just for its qualitative traits but due to an unquestionable essence.

While confirming GI as an effective strategic tool for development of rural enterprises, a study by the OECD (1995) pointed that the two main factors that influence the success of small rural enterprises are: market access and socially constructed differentiation

\section{Objective of the Study}

1) To provide an understanding of the concept of geographical indications.

2) To provide a historical backdrop of GI.

3) To discuss the parties interested in GI.

4) To lay down the legislation of GI in India.

5) To provide the legal framework of GI in India.

6) To analyse the famous case of Indian weave: Banarasi Brocade.

\section{Methodology}

This paper consists of conceptual framework of Geographical Indication and provides an insight to various aspects of it. The data has been gathered through secondary sources. Literature has been reviewed from readings, quotes and observations from legendary Intellectual Property Rights authors, newspapers, journals and newspaper leading to an analysis of the topic: GEOGRAPHICAL INDICATIONS IN INDIA \& THE CASE OF FAMOUS INDIAN WEAVE: BANARASI BROCADE

\section{History of GI}

Prior to the TRIPS agreement of the Uruguay round which concluded in 1994, there were mainly three international conventions dealing with protection of IGOs, i.e. the Paris Convention for the Protection of Industrial Property (1883), the Madrid Agreement (1891) and the Lisbon Agreement for the Protection of Appellations of Origin and their International Registration (1958). While the Paris Convention and the Madrid Agreement dealt with 'indications of source', the Lisbon Agreement focused on protection of 'appellations of origin' However, there remains the problem of a hierarchy in the levels of protection based on an arbitrary and specious categorisation of goods under the TRIPS Agreement. In international trade negotiations on IPRs, the European Union has always shown keen interest and even aggression in seeking effective protection to GI goods. The negotiations, particularly on the GI section of the TRIPS Agreement, were among the most difficult and this stemmed from clear division between the main proponents of the TRIPS agreement-the US and EU. The European Union constantly emphasised 
on inclusion of GI in the TRIPS during the Uruguay rounds of negotiation. The fact that GI was finally included in the TRIPS agreement can be attributed to the EU's remarkable negotiating capacity. The final outcome was tilted in the interest of the European countries. The Current TRIPS text provides a basic standard of protection to all other goods and higher standards of protection to wines and spirits in which they have clear advantages. The EU and its member states have a diverse portfolio of over 6,000 protected GIs. (Kasturi Das, 2006)

\section{Parties Interested in GI}

Worldwide Symposium on Geographical Indications organized by World Intellectual Properties Organisation (San Francisco, 2003) recognized the following parties interested in a geographical:

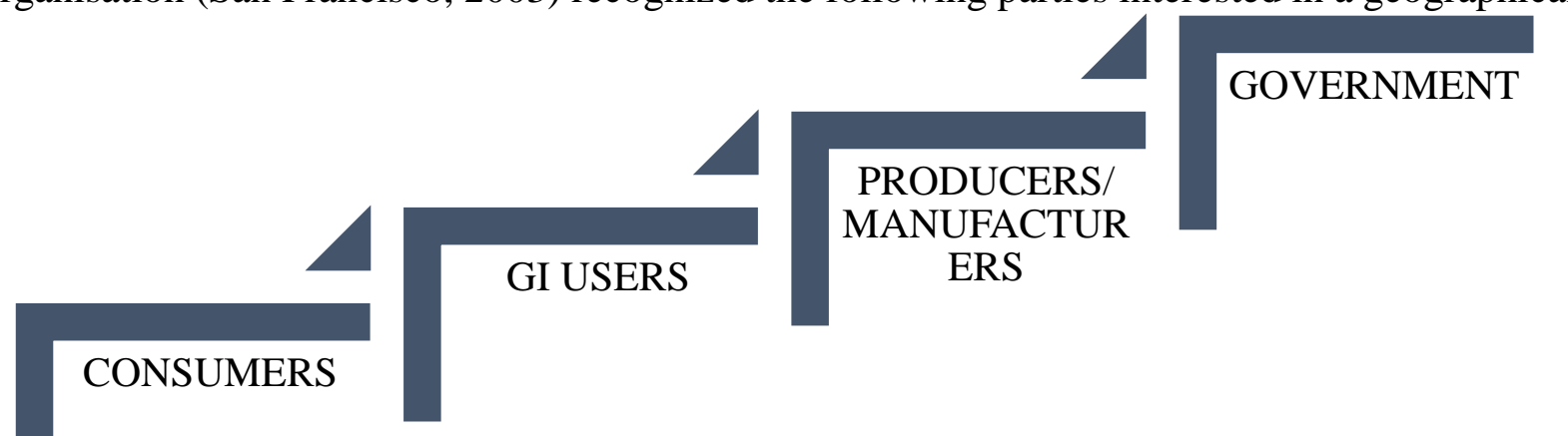

\section{i. $\quad$ Consumers}

Its every consumer's right to know about the product they buy. Characteristics and its origin form an essential part of this knowledge. When a product gains a GI tag, it gives the purchasers an assurance of its quality and that they are not being fooled or misled.

\section{ii. $\quad$ GI Users}

Their focus is on ease and wider scope of protections for GIs. The focus is to get access to foreign markets and to label their products with a GI ie a 'label uniformity'

\section{iii. $\quad$ Producers and Manufacturers}

A consumer survey done in Europe (WTO, 2004) revealed that 40 percent of consumers surveyed were willing to pay a premium as high as 10 percent.

The producer's and manufacturer's focus is on obtaining a generic name to their products so as to avoid confusion and overlaps and they also want 'label uniformity' that would lead to greater demands and higher revenues

\section{iv. Governments}

Their focus is to protect the health, welfare and human rights of their citizens. Protection of their consumers - from fraud, deception, confusion, etc.ie consumer protection. They also want to protect the economic interests of their domestic producers. 


\section{Geographical Indication in India}

European policies and studies conducted in this area emphasize the potential of GIs to improve rural livelihoods based on local resources (Pacciani et al, 2001)

How could India stand back? The first GI of was registered in 2004 with the advent of Darjeeling Tea and it has come a long way to the present of above 270.

The objective of introducing an act pertaining to GI in India ie Goods (Registration and Protection) Act, 1999 was:

1) Adequately protect the interest of producers of GI goods and add to the prosperity of the producers of such goods,

2) Protect consumers from deception, and

3) Promote goods bearing GI in the export market

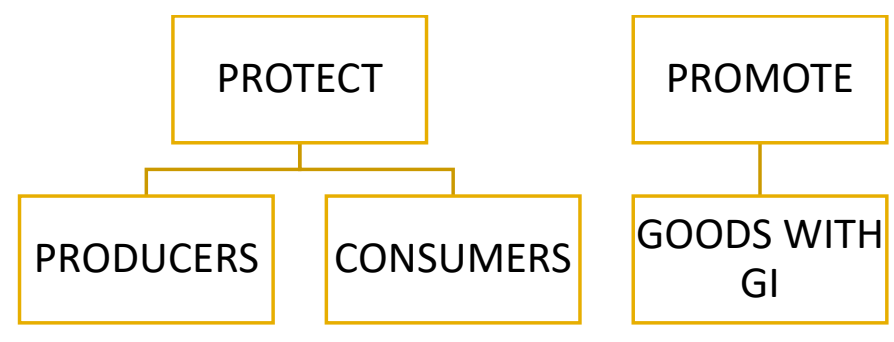

\section{India's Legislation for Geographical Indications}

In India the Geographical Indications of Goods (Registration and Protection) Act, 1999 came in force with effect from September 2003.

Section 2(e) of the Act defines a GI as: "geographical indication", in relation to goods, means an indication which identifies such goods as agricultural goods, natural goods or manufactured goods as originating, or manufactured in the territory of a country, or a region or locality in that territory, where a given quality, reputation or other characteristic of such goods is essentially attributable to its geographical origin and in case where such goods are manufactured goods one of the activities of either the production or of processing or preparation of the goods concerned takes place in such territory, region or locality, as the case may be.

1) Definitions and interpretation of several important terms like geographical indications goods, producers, package, registered proprietor, authorised user etc.,

2) Provision for the establishment of a geographical Indications Registry;

3) Provision for the maintenance of a Register of geographical Indications in two parts-part $\mathrm{A}$ and part B and use of computers, etc, for maintenance of such registers. While part A will contain all registered geographical indicators, part B will contain particulars of registered authorised users;

4) Registration of geographical indications of goods in specified classes

5) Prohibition of registration of certain geographical indications 
6) Provision for framing of rules by the central Government for filling of applications, its content and matters relating to substantive examination of geographical indications applications;

7) Compulsory advertisements of all accepted geographical indications applications and for inviting objections;

8) Registration of authorised users of registered geographical indications and providing infringement action either by a registered proprietor or authorised user;

9) Provision for the renewal, rectification and restoration of geographical indication and authorised use

10) Provision for higher level of protection for notified goods

11) Prohibition of assignment etc. of a geographical indications as it is public property

12) Prohibition of registration of geographical indications as a trade mark;

13) Appeal against registrar decisions

14) Provisions relating to offences and penalties

15) Provisions detailing the effects of registration and the rights conferred by registration;

16) Provision for reciprocity, power of registrar, maintenance of index, protection of homonymous geographical indication, etc.

To carry out the provision of this Act, the central Government notified a set of rules in 2002. The Government of India has established the 'Geographical Indications Registry' with all-India jurisdiction at Chennai, where the GIs can be registered. The controller General of Patents, Designs and Trademarks, who is also the registrar of Geographical Indication of India, is responsible for administering the GI Act. Till March 2010, 120 goods have been registered under the Act and many more are in the pipeline. Some of the well-known GI goods are 'Darjeeling' (tea), Pochhanpalli Ikat, Chanderi Handloom, 'Basmati' (rice), 'Alphonso' (mango), etc. (http://ipindia.nic.in/girindia)

\section{GOODS:}

Agricultural

Natural

$\begin{aligned} \text { Manufactured } & \rightarrow \text { Territory } \\ & \rightarrow \text { Region } \\ & \rightarrow \text { Locality }\end{aligned} \quad\left\{\begin{array}{l}\text { quality } \\ \text { reputation } \\ \text { characteristics }\end{array}\right\}$

Registration

While registration of GI is not mandatory in India, Section 20 (1) of the GI Act states that no person "shall" be entitled to institute any proceeding to prevent, or to recover damages for, the infringement of an "unregistered" GI. The registration of a GI gives its registered owner and its authorized users the right to obtain relief for infringement. The GI Registry with all India jurisdictions is located in Chennai with the Controller-General of Patents, Designs and Trade Marks is the Registrar of GIs, as per Section 3(1) of the GI Act. Section 6(1) further stipulates maintenance of a GI Register which is to be divided into two parts: Part A and Part B. The particulars relating to the registration of the GIs are incorporated in Part A, while the particulars relating to the registration of the authorized users are contained in Part B (Section 7 of the Act). A GI may be registered in respect of any or all of the goods, comprised in such class of goods as may be classified by the Registrar. The Registrar is required to classify the goods, as far as 
possible, in accordance with the International classification of goods for the purposes of registration of GI (Section 8 of the Act). A single application may be made for registration of a GI for different classes of goods and fee payable is to be in respect of each such class of goods.

\section{Duration}

In India a GI may initially be registered for a period of ten years, and it can be renewed from time to time for further periods of 10 years. Indian law place certain restrictions in that a registered GI is not a subject matter of assignment, transmission, licensing, pledge, mortgage or any such other agreement. (http://www.altacit.com/wp-content/uploads/2015/03/The-Protectionof-Geographical-Indication-in-India-Case-Study-on-Darjeeling-Tea.pdf)

\section{The Famous Indian Weave: Banarasi Brocade}

During the Mughal period, around 14th century, weaving of brocades with intricate designs using gold and silver threads was the specialty of Banaras. The Banarasi silk products have now joined the league of Pochampalli, Tirupati laddu and Darjeeling tea under the registered name of 'Banaras Brocades and Sarees' by securing Geographical Indication (GI) rights.

'Banaras brocades and saris' GI application was filed by 9 organisations viz. Banaras Bunkar Samiti, Human Welfare Association (HWA), joint director industries (eastern zone), director of handlooms and textiles Uttar Pradesh Handloom Fabrics Marketing Cooperative Federation, Eastern UP Exporters Association (EUPEA), Banarasi Vastra Udyog Sangh, Banaras Hath Kargha Vikas Samiti and Adarsh Silk Bunkar Sahkari Samiti.

Cheap raw material imports have led to the sale of what are known as Kela saris, in the name of Banarasi saris. These use banana tree resin to create threads which are then polished to give the look of silver or gold thread. Chinese imitation saris, pegged at much lower prices, are flooding the market. Moreover, there is a tenfold rise in the number of operating power-looms in the district of Varanasi itself, although certain other studies put higher estimates. Most power-loom owners have been producing cheap imitation products in large numbers to meet the growing demand, with computerised designs. Enforcement under the legal regime is frustrated further through absence of will on the part of GI holders to take action against the imitators. Despite the stakeholders being aware of the deleterious impact of sales of fake saris, complex market dynamics silence among all concerned. (http://www.teriin.org/div/briefing_paper_GI.pdf)

Interestingly support was received from not just India based NPOs but also organisations like UK-based Find Your Feet, Department for International Development and United Nations Conference on Trade and Development (UNCTAD) India in securing the GI status. They had been quite instrumental in helping India gain the GI tag and have taken several efforts to sustain the heritage weave to the nation. 


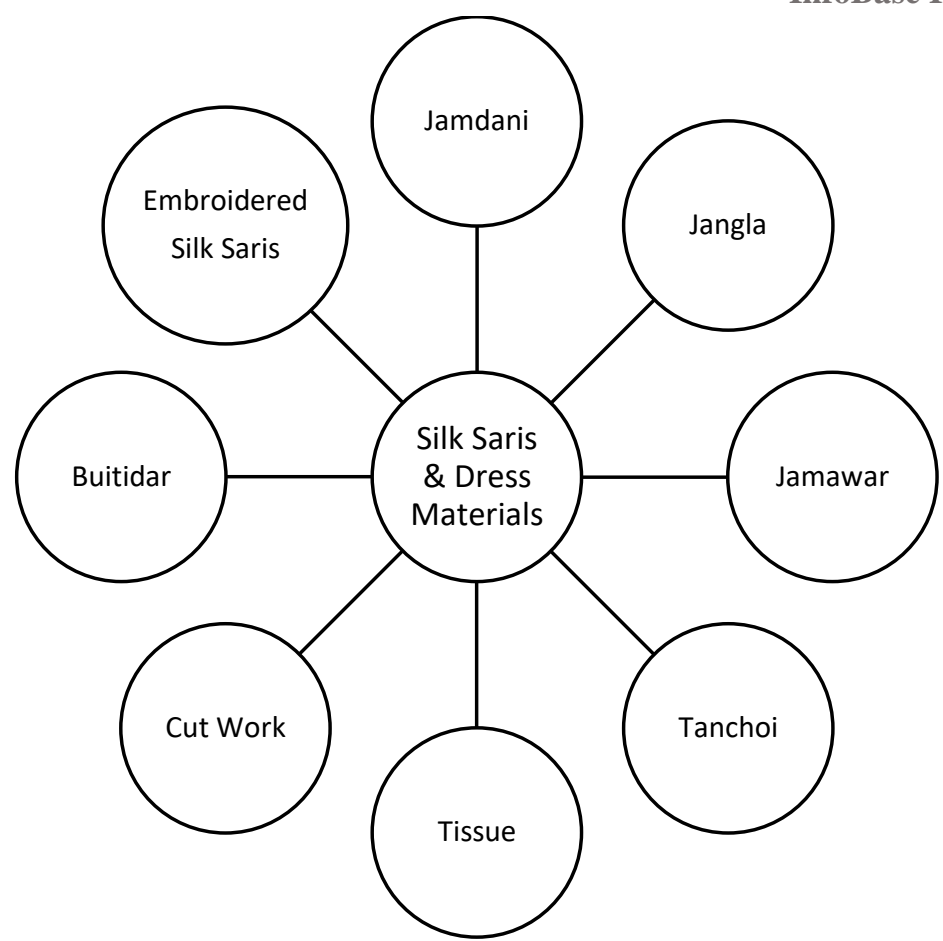

Under application no. 99 Banarasi brocade was granted GI on $3^{\text {rd }}$ September 2009

It is the finest Indian sari. The fine silk along with opulent embroidery teamed with silver-gold brocade makes them highly sought after and in demand. The intricacies from the Mughal era have its designs with intertwining foliate and floral motifs which form the characteristic features of these saris. The Banarasi silk saris are an undoubtedly inevitable part of any Indian bride's trousseau. Wearing these saris is part of all important events of an Indian woman which is accompanied by traditional gold/silver jewellery.

The Banarasi Silk Sari gets its recognition in the name of 'Banaras Brocades and Sarees'. Banarasi Bunkar Samiti, an organization of Banarasi handloom weavers along with 8 other organizations had initiated the effort to receive the right to the Banarasi silk product. The Banarasi sari has been facing a lot of competition recently from saris manufactured in cities like Bhagalpur, Surat and Bangalore and the Geographical Indication is expected to cut the duplicates which are tagged off as Banarasi. Almost 12 lakh people associated directly or indirectly with the silk industry benefit from the GI status as this would restrict the misuse of the brand name Banarasi Sari.

\section{Section (23-26) Silk Embroidery \\ GI Certificate of \\ Banarsi Brocade Textile Goods}

Silk Brocades

Silk Sari

Dress Material 
According to the GI certificate, Banarasi silk product fall under four classes (23-26) namely silk embroidery, textile goods, silk brocades, silk sari and dress material. The most important aspect of the GI certification is that no brocade or sari made outside the six identified districts of Uttar Pradesh, India can legally be sold as Banarasi sari and Brocade. The certificate states that henceforth only saris produced in Varanasi, Azamgarh, Chandauli, Jaunpur, Mirzapur and Sant Ravi Dass Nagar (Bhadohi) will be considered Banarasi saris. The certificate covers silk brocades like Amru; textile goods not covered elsewhere such as bed and table covers; silk saris and dress materials such as jamdani, jangla, jamawar tanchoi, tissue, cut work, 'butidar' and silk embroidery saris. (http://www.vaastuyogam.com/2010/11/coporate-logos-geographicalindication/)

\begin{tabular}{ll}
\hline Certificate & Varanasi \\
$\begin{array}{l}\text { States for } \\
\text { Banarasi } \\
\text { Brocade }\end{array}$ & Azamgar \\
\cline { 2 - 2 } & Chandauli \\
\cline { 2 - 2 } & Jaunpur \\
\hline Mirzapur \\
\hline Bhadohi \\
\hline
\end{tabular}

\section{Why it was important to get Banarasi Brocade a GI tag?}

The tag which has been granted for a period of 10 years can be extended for another ten as and when the situation arises. For now it was essential to get it registered as a geographical indication making it the first tag from Uttar Pradesh's Eastern area covering Varanasi, Mirzapur, Chandauli, Bhadohi, Jaunpur and Azamgarh districts.

The tag's achievement is aimed at benefitting not just lakhs of handloom weavers but also consumers and exporters making the fine Indian weave not just an international mark but assuring consistent quality that distinguishes it from others. The GI sets weavers' work apart from cheap imitations, helping them to protect their livelihoods, their craft and their identity.

The Ministry of Textiles, Government of India has started many schemes for the handloom weavers like - Handloom Mark, Health Insurance Scheme post registration this has added to the confidence of the weavers.

One of the most instrumental organisations in the GI tag of Banarasi Saris feel that this was one move that shall help indian weavers with some relief in respect of the efforts put in by them. They quoted:

"In 2009 our work supporting the weavers of Varanasi to achieve a Geographical Indicator bore fruit. The GI is expected to bring a number of benefits: it will protect consumers, who will be sure they are getting a genuine, quality Benarsi sari; it will protect the weavers, by conferring legal protection against unfair competition (i.e. cheap imitation saris); it will add value to 
Benarsi saris, helping to secure a premium price in the market; and it will help to preserve local knowledge and traditions among rural weaving communities.

In order to support the weavers to make sure that the benefits of the GI reach the weavers we will be supporting them to market and diversify their product, among other things." Find Your Feet

After a wait of two years, and having benefitted more than ten lakh people, GI has been a landmark in providing relief to Indian handloom workers.

"It is a big achievement for the people associated with the Banarasi saree industry. In this era of globalisation, it is essential to get the GI status," said Ashok Kapoor, the founder member of EUPEA.

\section{Conclusion}

A GI tag is a matter of pride to both the producer and consumer as a symbol of quality, and a sense of surety of originality and safety of rights to the parties involved. Intellectual property rights covering geographical indication has taken a place in India due to the original pieces of work in not just textile, art and craft but spices, cinema etc. having their homeland in the boundary of India. Geographical indications have been a boon to people around the world specially the poor craftsmen who put in their best efforts to maintain such quality that is known and retained worldwide. A GI tag is an essential component to maintain and retain the essence and originality of a product of certain features and characteristics. India hasn't been left behind in legitimately taking this aspect of intellectual property right forward. With a house of above two hundred GI's India isn't lagging behind and Banarasi brocade and sari continues to be the finest weave and one of the most famous textiles and getting it a tag was one of the wisest decision for the economy as a whole.

\section{References}

[1] Das, Kasturi (2006), Protection of Geographical Indications: An overview of select Issues with Special reference to India, Working Paper, 8;Centad,Delhi

[2] Das, Kasturi (2009), Socioeconomic Implications of Protecting Geographical Indications in India, WTO Centre, IIFT, New Delhi.

[3] EU Background Note, 'Why do Geographical Indications Matter to Us?' 2004

[4] Times of India, September 17, 2009 http://timesofindia.indiatimes.com/city/varanasi/Banarasisilk-gets-GI-recognition/articleshow/5023601.cms\#

[5] TERI Briefing Paper 'The Protection of Geographical Indications in India: Issues and Challenges' http://www.teriin.org/div/briefing_paper_GI.pdf

[6] https://papers.ssrn.com/sol3/papers.cfm?abstract_id=1587352

[7] https://papers.ssrn.com/sol3/papers.cfm?abstract_id=1587372

[8] http://www.wipo.int/geo_indications/en/

[9] World Intellectual Property Organisation /Geographical Indications http://www.wipo.int/edocs/mdocs/geoind/en/wipo_geo_sfo_03/wipo_geo_sfo_03_22-part1.pdf

[10] World Intellectual Property Organisation /Geographical Indications http://www.environmentallawsofindia.com/geographical-indications-of-goods.html 
[11] http://www.vaishlaw.com/article/indian_intellectual_property_laws/laws_of_geographical_indica tions_plant_varieties_in_india.pdf?articleid=100324

[12] http://www.altacit.com/wp-content/uploads/2015/03/The-Protection-of-Geographical-Indicationin-India-Case-Study-on-Darjeeling-Tea.pdf

[13] http://www.vaishlaw.com/article/indian_intellectual_property_laws/laws_of_geographical_indica tions_plant_varieties_in_india.pdf?articleid=100324

[14] http://eprints.rclis.org/7878/1/EF6C0C53.pdf

[15] Corporate Logos - Geographical Indication:http://www.vaastuyogam.com/2010/11/coporatelogos-geographical-indication/

[16] http://www.merinews.com/article/banarasi-sari-weavers-face-povertyhunger/15884815.shtml\&cp

[17] Find Your Feet http://think-style.blogspot.in/2011/06/find-your-feet.html

*Corresponding author.

E-mail address: gulati_shruti@yahoo.co.in 